\title{
Syphilis Diagnosis through Oral Lesions of Different Clinical Aspects: Report of 3 Cases
}

\section{Diagnóstico de Sífilis Através de Lesões Bucais de Diferentes Aspectos Clínicos: Relato de 3 Casos}

\author{
Matheus Bruno Costa ${ }^{\mathrm{a}}$ Erika Terumi Tomisaki ${ }^{\mathrm{a}}$ Fabio Augusto Ito ${ }^{\mathrm{a}}$; Heliton Gustavo de Lima ${ }^{\mathrm{a}}$; Willian Ricardo Pires ${ }^{\mathrm{a}}$; \\ Ademar Takahama Junior ${ }^{a}$
}

${ }^{a}$ Universidade Estadual de Londrina, Dentistry course. PR, Brasil.

*E-mail: ademartjr@hotmail.com.br

\begin{abstract}
Syphilis is a sexually transmitted infection, caused by the anaerobic spirochete Treponema pallidum. It is characterized by a variety of clinical manifestations including the oral mucosa, mimicking several diseases, thereby making diagnosis a challenge for clinicians. Therefore, the objective of this work is to report three cases of syphilis that were diagnosed based on oral lesions of different clinical aspects. In this series of cases, the lesions were found on the tongue and hard palate and presented as white plaques, ulcers or erythematous spots associated with ulcers. In the two cases, incisional biopsy was performed, and the histopathological aspects were suggestive of syphilis. Treponemic and nontreponemic tests were positive for all the patients, confirming syphilis. Therapy with benzathine-penicillin, administered intramuscularly led to complete remission of oral lesions in all the patients. The syphilis reemergence in the last years demands its inclusion in the differential diagnosis of several oral lesions. Diagnosing syphilis by oral lesions can be difficult once it can mimic other conditions. Therefore, dentists should know the clinical aspects of this infection, since many cases may exhibit only oral manifestations, to help in the diagnosis and control of the infection spread.
\end{abstract}

Keywords: Syphilis. Treponemal Infections. Oral Manifestations.

\section{Resumo}

A sifilis é uma infecção sexualmente transmissível, causada pela espiroqueta anaeróbia Treponema pallidum. É caracterizada por uma variedade de manifestações clínicas, incluindo a mucosa oral, podendo mimetizar várias doenças, tornando o diagnóstico um desafio. Portanto, o objetivo deste trabalho é relatar três casos de sifilis diagnosticados a partir de lesões orais de diferentes aspectos clínicos. Nesta série de casos, as lesões foram encontradas na língua e palato duro e apresentadas como placas brancas, úlceras ou manchas eritematosas associadas a úlceras. Em dois casos, foi realizada biópsia incisional e os aspectos histopatológicos foram sugestivos de sifilis. Os testes treponêmicos e não treponêmicos foram positivos para todos os pacientes, confirmando a sifilis. A terapia com penicilina benzatina, administrada por via intramuscular, levou à remissão completa das lesões orais em todos os pacientes. O ressurgimento da sifilis nos últimos anos exige sua inclusão no diagnóstico diferencial de várias lesões bucais. O diagnóstico da sífilis por lesões orais pode ser difícil, pois pode mimetizar outras condições. Portanto, o dentista deve conhecer os aspectos clínicos dessa infecção, pois muitos casos podem apresentar apenas manifestações orais, para auxiliar no diagnóstico e controle da disseminação da infecção.

Palavras-chave: Sifilis. Infecção Treponêmica. Manifestações Orais.

\section{Introduction}

Syphilis is a sexually transmitted infection, which has as etiological agent the bacterium from the spirochete group Treponema pallidum. It can be sexually transmitted (acquired syphilis) and vertically spread via the placenta (congenital syphilis). This infection remains a serious public health problem, being among the five most reported infectious diseases worldwide and is the most frequently reported sexually transmitted infection in Brazil. In recent years, there has been an increase from 34.1 to 75.8 cases per 100,000 inhabitants between the years 2015 and $2018^{1}$.

Based on its activity and stages of infection, it is classified into four stages: primary, secondary, latent and tertiary ${ }^{2-5}$. However, the World Health Organization classifies infection in two stages: the former, being the first year of infection (covering the primary, secondary, and early latent stages) and the later, where it covers the latent and tertiary stages ${ }^{4-6}$.

Primary syphilis has a characteristic lesion called hard chancre. This lesion is usually a painless ulcer with a hard raised edge, which is extremely contagious and appears at the bacteria site of inoculation. Although not common, hard chancre can also be extragenital, affecting mainly anal or oral sites. The lesions disappear spontaneously within a few days leaving no scars ${ }^{4-9}$. The period for the lesions to appear may vary between 10 and 90 days ${ }^{4,5,7}$. Microscopically, it is characterized by a proliferation of blood vessels surrounded by lymphocytes, macrophages and plasma cells ${ }^{10,11}$. In hematoxylin and eosin (HE) staining, the epithelial surface is ulcerated, with the presence of intense chronic inflammatory infiltrate predominantly of lymphocytes and plasma cells, 
generally with perivascular pattern ${ }^{12}$.

The secondary syphilis stage reflects the bacterium hematological and lymphatic dissemination, appearing in approximately 8 weeks after the primary lesion, still being contagious. Usually there are cutaneous and systemic manifestations such as skin eruptions that may present a palmoplantar pattern, headache, low fever, anorexia, weight loss, myalgia, arthralgias, pharyngitis, hoarseness, and increased lymph nodes ${ }^{4,7}$. Oral lesions appear in approximately $30 \%$ of those infected ${ }^{3,5,9}$. The most common oral lesions of the secondary stage are mucosal plaques and maculopapular lesions; however, several oral lesions of different clinical aspects have been reported in the literature in recent years, mainly due to the resurgence of this infection ${ }^{2-7,9}$. Because of these varied clinical manifestations, syphilis has been known as "the great imitator"-2.4. Microscopically, an inflammatory infiltrate containing monocytes recruited from the peripheral circulation and increased angiogenesis is observed ${ }^{10,11}$. The surface may be ulcerated or hyperplastic with spongiosis and exocytosis, associated with a deep and dense underlying plasmocytic inflammatory infiltrate ${ }^{12}$. Untreated primary and secondary syphilis may progress to the latent stage, which patients remain asymptomatic and free of lesions, but respond positively to serological tests, and may last up to 30 years ${ }^{4,5}$. In recent latent syphilis, usually in the first 12 months, infected patients transmit the bacteria; however, in the late stage of latent syphilis, infectivity decreases".

Approximately $33 \%$ of the untreated patients during the previous stages will evolve to the tertiary stage, which can be from 1 to 30 years after contamination. Tertiary syphilis is the most severe stage of infection and can affect the nervous and cardiovascular systems, skin and mucous membranes ${ }^{4,5,9}$. Usually, the main characteristic of tertiary lesions is the destructive granulomas formation (gummas). Intraorally, the gumma is often seen on the hard palate as a chronic, progressive, granulomatous lesion that may perforate through the palatal bone into the nasal septum. The tongue is rarely affected, and the common lesions on its dorsum are: atrophic, fissured, lobulated or leukoplakic lesions. Histologically, an ulcerated area with pseudoepitheliomatous hyperplasia is observed, with granulomatous inflammatory infiltration, containing histiocytes and multinucleated giant cells ${ }^{12}$. It is important to emphasize that tertiary syphilis is not contagious.

Beyond the horizontal transmission, the bacteria can be transmitted vertically, causing congenital syphilis. According to the Ministry of Health's Epidemiological Bulletin ${ }^{1}$, there was an increase in the congenital syphilis detection rate from 2.4 cases in 2010 to 9.0 cases per thousand live births in 2018 . Contamination occurs when Treponema pallidum crosses the placental barrier between the 9th and 16th week of gestation or during childbirth, if there is contact with the mother's genital lesions. This form of transmission usually results in abortion, stillbirth and congenital malformations ${ }^{4}$. The first signs usually appear between 2 and 3 weeks of life of the surviving babies, and the main ones are fever, growth retardation, jaundice, anemia, hepatosplenomegaly, rhinitis, rhagades and cutaneous eruption. Children who have not received treatment and survive tend to develop tertiary syphilis, causing damage to bones, teeth, eyes, ears, and brain. Dental changes are known as Hutchinson's incisors and mulberry molars ${ }^{4}$.

The diagnosis is made through serologic treponemic and non treponemic tests, especially the VDRL (Venereal Disease Research Laboratory) and FTA-ABS (Fluorescent Treponemal Antibody Absorption Test) ${ }^{5,6,9}$. The treatment is performed with benzathine penicillin, but in cases where the patient is allergic, doxicillin is the second line of treatment $t^{4}$.

The purpose of this study is to report three cases of syphilis diagnosed through oral lesions with different clinical aspects. All the cases were attended at the Stomatology Clinic of the State University of Londrina .

\section{Case Report}

\subsection{Case 1}

A 23-year-old Caucasian man sought our service complaining of "small white plaques under the tongue on both sides". During the anamnesis, he reported that asymptomatic white plaques appeared on the tongue bilaterally. In his medical history no relevant aspects were observed and extraoral physical examination found no abnormalities. Intraoral examination revealed two white plaques on the lateral border of the tongue bilaterally. The lesion on the right side was approximately $0.7 \mathrm{~cm}$ in size, well defined, irregular in shape, flat edges and painless on palpation. On the left side, besides the white plaque, an erosion area was also noted (Figure 1).

Figure 1A - White plaque and erosion area located on the tongue left lateral border. 1B - White plaque located on the tongue right side.

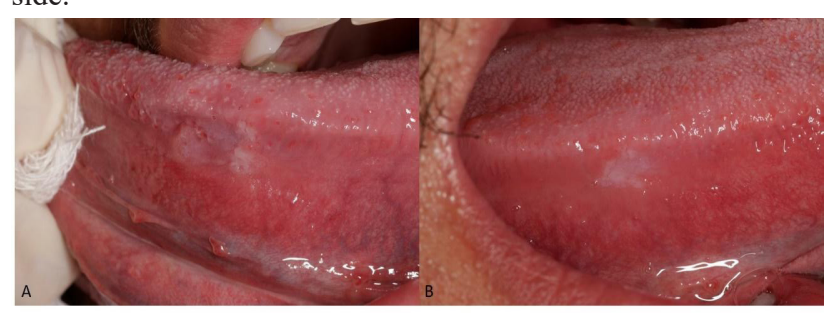

Source: The authors.

According to these characteristics, the diagnostic hypotheses were traumatic hyperkeratosis, squamous cell carcinoma (SCC) and syphilis. A complete blood count (CBC) was requested, as well as VDRL and FTA-ABS tests for syphilis serology. An incisional biopsy was also performed on the left side, due to the SCC hypothesis. Microscopically, a fragment of mucosa lined by a stratified squamous parakeratinized epithelium was observed, showing mild spongiosis and leukocyte exocytosis. The underlying connective tissue presented a focal area of perivascular inflammatory infiltrate 
with predominance of plasma cells. (Figure 2).

Figure 2 - Photomicrograph of biopsy specimen showing connective tissue with a focal area of perivascular inflammatory infiltration with predominance of plasma cells

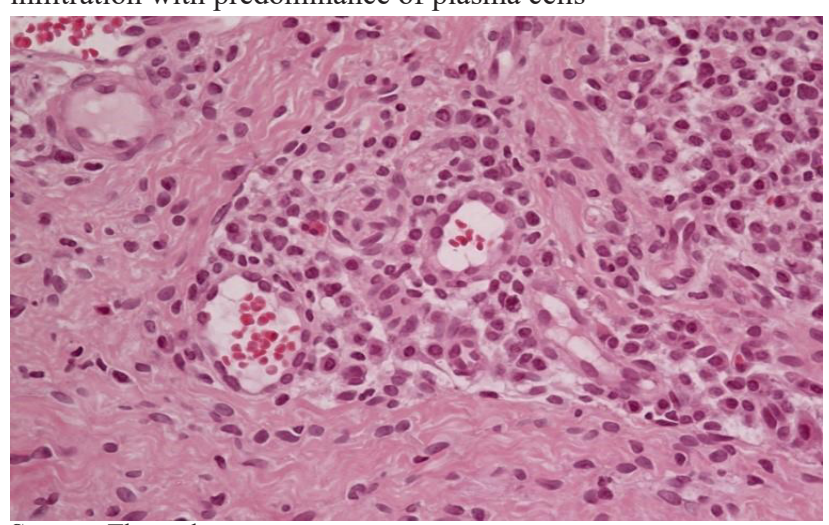

Source: The authors.

The CBC showed no changes and the serological tests confirmed the syphilis diagnosis, with VDRL reagent 1:32 and FTA-ABS reagent. After confirming the diagnosis, the patient was referred to the infectious disease specialist for treatment. Two doses of benzylpenicillin benzathine were applied. After the treatment, the patient returned to our service with total remission of the lesions (Figure 3).

Figure 3 - A and B - Clinical aspect showing total remission of lesions in the patient of case 1 after treatment

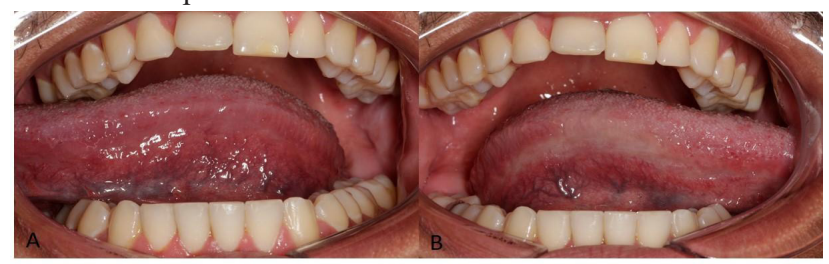

Source: The authors.

\subsection{Case 2}

A 47-year-old Caucasian woman was referred to our service, complaining of "pain in the mouth for about 1 month". In the anamnesis, the patient reported that about a month ago had symptoms of fever and fatigue, and after that, the appearance of painful oral lesions. She reported a previous diagnosis of syphilis 30 years ago, being treated with Benzylpenicillin. She also reported recent unprotected sexual intercourse. During physical examination, an erythematous area was observed in the transition between hard and soft palate, associated with circular ulcers at the anterior part of the lesion (Figure 4). Two small ulcers were also found on the left buccal mucosa. The diagnostic hypotheses for this case were: secondary syphilis, traumatic ulcers and erythroplakia. The CBC, VDRL and FTA-ABS were requested. CBC was normal and the VDRL test was reagent 1:256 and the FTA-ABS was also reagent, confirming the syphilis diagnosis. The patient was treated with 6 doses of benzylpenicillin benzathine. After the treatment, the patient returned for evaluation, and total regression of lesions was observed (Figure 5).
Figure 4 - Erythematous area in the transition between hard and soft palate, on the midline, with presence of a small circular ulcer on the anterior part of the lesion.

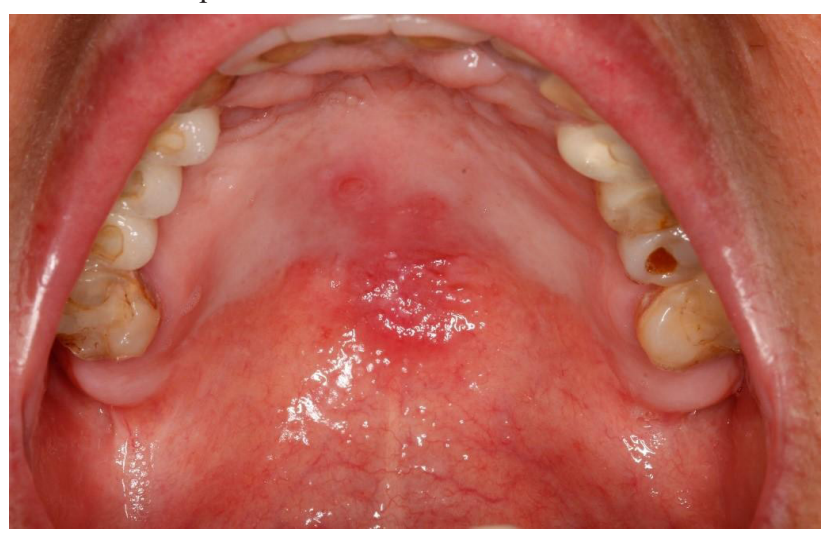

Source: The authors.

Figure 5 - Clinical aspect showing total remission of lesions after treatment in the patient of case 2 .

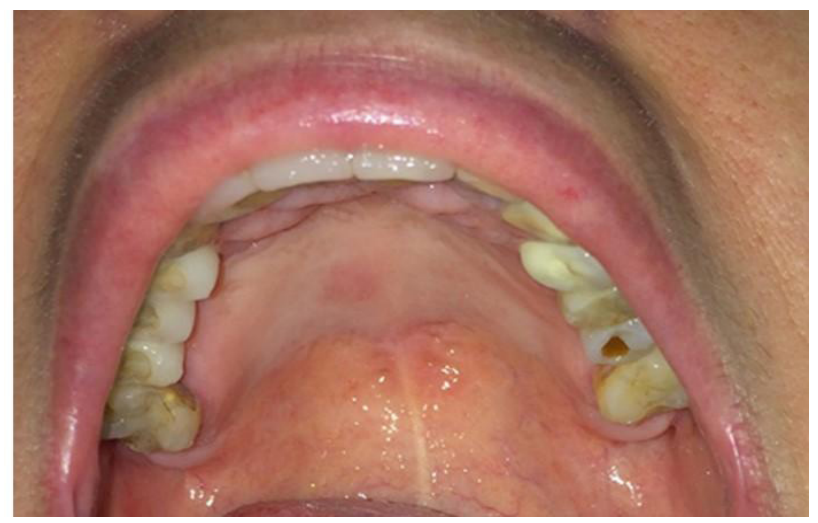

Source: The authors.

\subsection{Case 3}

A 46-year-old Caucasian man was referred to our service complaining of a "non-healing wound in the tongue for about 45 days". The patient reported a previous consultation cwith a doctors and dentists, being treated with topical corticosteroids without any improvement. On extraoral examination, palpable left submandibular lymphnodes were found. The intraoral examination revealed a superficial circular ulcer located on the anterior dorsum of the tongue (Figure 6). The clinical diagnostic hypotheses were syphilis and eosinophilic ulcer. An incisional biopsy was performed and a $\mathrm{CBC}$ and serological tests for syphilis (VDRL and FTA-ABS) were requested. Microscopically, a fragment of ulcerated mucosa with intense deep chronic inflammatory infiltration was observed, presenting areas of perivascular inflammatory infiltration, rich in plasma cells (Figure 7). The CBC was normal, the VDRL was 1:8 and the FTA-ABS reagent, confirming the syphilis diagnosis. The patient received treatment similar to the previous case and total remission of the lesion was observed (Figure 8). 
Figure 6 - Superficial ulcer located on the right side of the tongue dorsum.

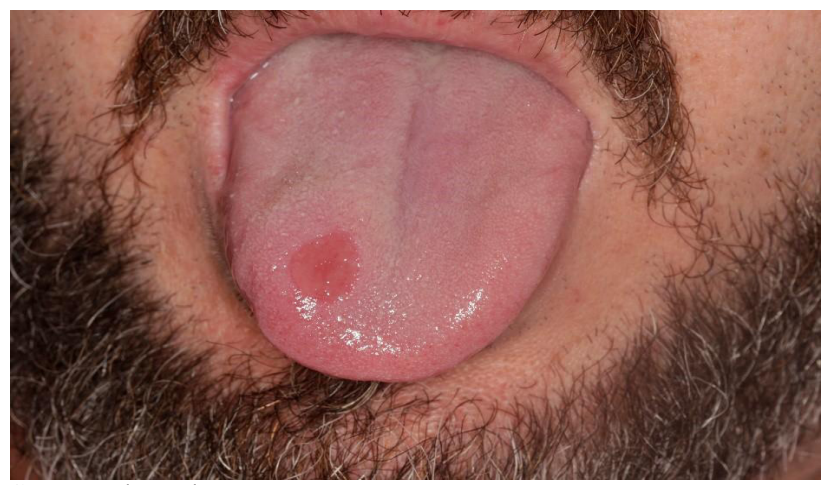

Source: The authors.

Figure 7 - Photomicrograph of biopsy specimen containing an ulcerated mucosa fragment with intense deep chronic inflammatory infiltrate (HE, 40x).

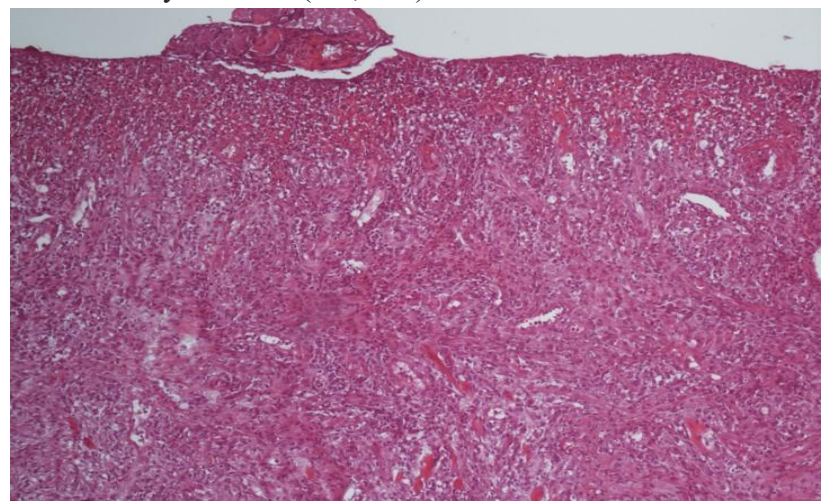

Source: The authors.

Figure 8 - Clinical aspect showing total remission of lesions after treatment in the patient of case 3

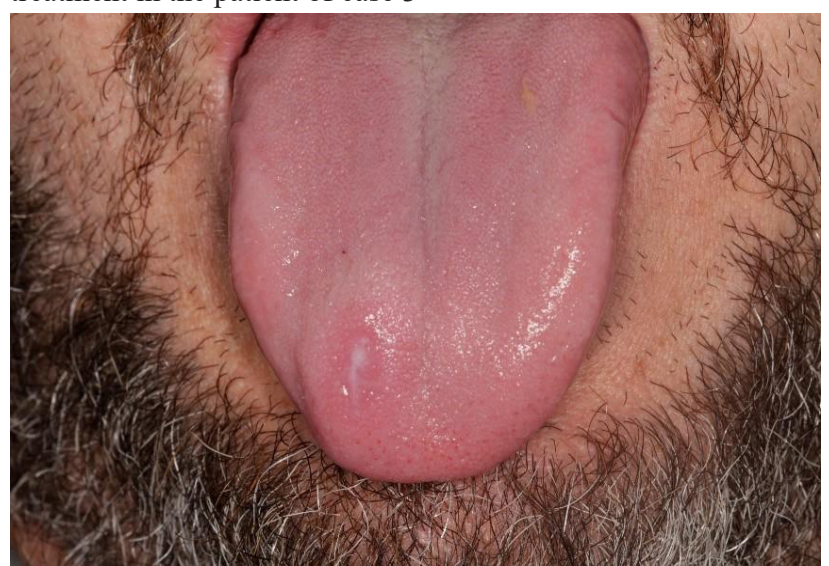

Source: The authors.

\section{Conclusion}

This case series shows different clinical aspects of oral syphilis manifestations, a reemerging disease in Brazil that has currently become an epidemy, and consequently, a public health problem. This quickly and recent increase in the number of cases, along with its variable clinical presentation and the incomplete information provided by the patient, reinforces the urgent need to include this disease in the differential lesions diagnosis affecting the oral mucosa. Therefore, dentists should have knowledge about the main signs and symptoms of this infection in order to make a correct diagnosis, referring the patient to the appropriate treatment, thus helping the epidemic control.

\section{References}

1. Brasil. Ministério da Saúde. Secretaria de vigilância em saúde. Bol Epidemiol Sífilis 2019;5(1).

2. de Paulo LFB, Servato JPS, Oliveira MTF, Durighetto Jr AF, Zanetta-Barbosa D. Oral manifestations of secondary syphilis. Int J Infect Dis 2015;35:40-2. doi: https://doi. org/10.1016/j.ijid.2015.04.007

3. Compilato D, Amato S, Campisi G. Resurgence of syphilis: a diagnosis based on unusual oral mucosa lesions. Oral Surg Oral Med Oral Pathol Oral Radiol Endod 2009;108:45-9. doi: https://doi.org/10.1016/j.tripleo.2009.05.013

4. Kalinin Y, Neto AP, Passarelli DHC. Sífilis: aspectos clínicos, transmissão, manifestações orais, diagnóstico e tratamento. Odonto 2015;23(45-6):65-76. doi: http://dx.doi. org/10.15603/2176-1000/odonto.v23n45-46p65-76

5. Valente T, Scalercio M, Israel M, Ramos ME. Diagnóstico da sífilis a partir das manifestações bucais. Rev Bras Odontol 2008;65(2):159-64. doi: http://dx.doi.org/10.18363/rbo. v65n2.p.159

6. Soares AB, Gonzaga HFS, Jorge MA, Barraviera SRCS. Oral manifestations of syphilis: a review. J Venom Anim Toxins incl Trop Dis 2004;10(1):2-9. doi: http://dx.doi.org/10.1590/ S1678-91992004000100002

7. De Souza B. Manifestações clínicas orais da sífilis. RFO 2017;22(1):82-5. doi: https://doi.org/10.5335/rfo.v22i1.6981

8. Streight KL, Paranal RM, Musher DM. The oral manifestations of syphilitic disease: a case report. J Med Case Rep 2019;13(1):227. doi: https://doi.org/10.1186/s13256019-2171-z

9. Leão JC, Gueiros LA, Porter SR. Oral manifestations of syphilis. Clinics 2006;61(2):161-6. doi: http://dx.doi. org/10.1590/S1807-59322006000200012

10. Lin SW, Gao ZX, Lin LR,X, Liu LL, Yang TC. Treponema pallidum enhances human monocyte migration and invasion by dysregulating the MMP/TIMP balance. Int Immunopharmacol 2019;75:105744. doi: https://doi. org/10.1016/j.intimp.2019.105744

11. Gao ZX, Luo X, Liu LL, Lin LR, Tong ML, Yang TC. Recombinant Treponema pallidum protein $\mathrm{Tp} 47$ induces angiogenesis by modulating the matrix metalloproteinase/ tissue inhibitor of metalloproteinase balance in endothelial cells. J Eur Acad Dermatol Venereol 2019;33(10):1958-70. doi: https://doi.org/10.1111/jdv.15725

12. Andrade RS, Freitas EM, Rocha BA, Gusmão ES, Filho MRM, Júnior HM. Oral findings in secondary syphilis. Med Oral Patol Oral Cir Bucal 2018;23:138-43. doi: 10.4317/ medoral.22196. 